\title{
PENGGUNAAN FLY ASH SEBAGAI BAHAN TAMBAH PADA PROSES PEMBUATAN MORTAR DENGAN BAHAN DASAR PASIR APUNG
}

\author{
Dahri Kabir*1, Imran 2, Mufti Amir Sultan3 \\ 1, Alumni Teknik Sipil, Fakultas Teknik Universitas Khairun, Ternate \\ 2,3 Program Studi Teknik Sipil, Fakultas Teknik Universitas Khairun, Ternate \\ *e-mail: kabirdahri012@gmail.com \\ Manuscript received: 16-09-2018, Revision accepted: 05-11-2018
}

\begin{abstract}
Abstrak
Sumber daya alam yang terdapat di Kota Tidore Kepulauan, salah satunya berupa ketersediaan batu apung,yang telah dimanfaatkan untuk membuat bata pres. Di Kota Tidore juga terdapat abu batubara (fly ash) yang berasal dari PLTU yang dapat mengganggu kenyamanan masyarakat sehingga batu bara ini dicoba untuk bahan campuran bata semen untuk mengurangi berat semen dalam pembuatan bata semen. Tinjauan pada penelitian ini berupa sifat-sifat mekanis bata batu apung dan tahapan yang dilakukan antara lain: pengujian karakteristik material, perencanaan komposisi campuran 1PC: 4PS, dan variasi limbah batu bara fly ash yang digunakan yaitu $0 \%, 10 \%, 20 \%, 30,40 \%$ dan $50 \%$ dengan jumlah sampel 60 buah. Hasil dari penelitian ini adalah semakin besar bahan tambah fly ash semakin tinggi nilai kuat tekan, untuk bahan tambah fly ash sebagai bahan tambah semen menghasilkan kuat tekan bata $133,88 \mathrm{~kg} / \mathrm{cm}^{2}, 150,87 \mathrm{~kg} / \mathrm{cm}^{2}, 161,06 \mathrm{~kg} / \mathrm{cm}^{2}, 196,40 \mathrm{~kg} / \mathrm{cm}^{2}, 243,29 \mathrm{~kg} / \mathrm{cm}^{2}$, dan 243,29 $\mathrm{kg} / \mathrm{cm}^{2}$. Dalam syarat-syarat fisis menunjukan bata semen pasir apung berada pada tingkat mutu bata semen mutu I.
\end{abstract}

Kata kunci: batu apung, fly ash, mortar.

\section{PENDAHULUAN}

Dewasa ini banyak industri telah mengganti sumber tenaga pada pembangkit uap dari bahan bakar minyak bumi dengan batubara, sebagai akibat langka dan mahalnya harga bahan bakar tersebut. Penggunaan batubara sebagai sumber energi pada unit mesin uap pada industri telah menjadi pilihan yang paling diminati termasuk pembangkit listrik yang ada di wilayah Kota Tidore Kepulauan yaitu PLTU Rum. Abu terbang ( $f l y$ ash) merupakan limbah padat yang dihasilkan dari pembakaran batubara pada pembangkit tenaga listrik. Limbah padat ini terdapat dalam jumlah yang cukup besar, sehingga memerlukan pengelolaan agar tidak menimbulkan masalah lingkungan, seperti pencemaran udara, perairan dan penurunan kualitas ekosistem. Abu terbang batubara umumnya dibuang atau ditumpuk begitu saja di dalam area PLTU. Penumpukan abu terbang batubara ini dapat menimbulkan masalah bagi lingkungan. Pemerintah berusaha mengembangkan industri yang bersih lingkungan, dan mengembangkan penelitian mengenai pemanfaatan abu terbang batubara yang terus dilakukan guna meningkatkan nilai ekonomisnya.

Mortar merupakan campuran yang terdiri dari agregat (pasir), air, dan semen pada proporsi tertentu sebagai bahan perekat. Penerapan mortar lebih cenderung pada pekerjaan non- 
struktural seperti bata semen yang umum digunakan olah masyarakat Maluku Utara. Bata semen mempunyai bobot yang lebih berat dibandingkan dengan batu bata dari tanah liat. Dengan bobot yang lebih berat dapat meningkatkan beban mati dari suatu konstruksi. Beberapa penelitian penggunaan pasir apung/batu apung sebagai bahan mortar antara lain: Sultan dan Yudasaputra (2017), meneliti penggunaan pasir apung sebagai pengganti pasir pada campuran mortar. Dari penelitian disimpulkan bahwa penggunaan mortar pasir apung sebagai bahan bata semen, lebih ringan $44,14 \%$ dibanding pasir biasa/bukan pasir apung. Pengaruh penambahan fly ash dan conplast pada mortar pasir apung dan pasir sungai mengakibatkan kuat tekan yang lebih besar dari mortar normal (Simanullang, 2014). Pemberian tekanan atau beban pada proses pembuatan mortar pasir apung dapat memperbaiki kinerja mortar pasir apung tersebut (Sultan et al, 2018).

Penelitian dengan pemanfaatan fly ash pada campuran mortar antara lain: Penggunaan fly ash sebagai campuran bata semen, memiliki potensi untuk pengembangan baru bangunan ramah lingkungan, ekonomis dan material aman (Mystri et al, 2011). Penggunaan fly ash PLTU Amurang sebagai bahan subtitusi parsial semen pada pembuatan mortar dapat memperbaikai sifat mortar tersebut (Wenno dkk, 2014). Penambahan fly ash dalam mortar tipe M dapat memperkecil volume void atau pori-pori yang ada (Kusdiyono dan Rohadi, 2012). Penelitian dengan penambahan fly ash pada kadar 30\% dalam campuran bata ringan dapat menghasilkan hasil yang lebih baik dan ekonomis dibandingkan dengan perekat bata ringan standar tanpa fly ash. (Karijanto dkk, 2013). Penggunaan abu terbang asam-asam Kalimantan Selatan pada campuran bata beton dengan komposisi $0,50 \%$ dan $0,38 \%$ dengan foam dan polimer menghasilkan bata tingkat IV berdasarkan SNI (Haryanti, 2015). Limbah batu bara fly ash dan bottom ash dapat dimanfaatkan sebagai bahan agregat dalam pembuatan bata beton ringan yang kualitasnya memenuhi syarat minimal untuk konstruksi pasangan dinding bangunan rumah. (Ola dan Silaban, 2018).

SNI 03-0349-1989 telah mengatur syarat-syarat fisis bata beton atau bata semen seperti pada Tabel 1.

Tabel 1. Syarat-Syarat Fisis Bata Beton

\begin{tabular}{|c|c|c|c|c|c|c|c|c|c|}
\hline \multirow{2}{*}{ Syarat fisis } & \multirow[t]{2}{*}{ Satuan } & \multicolumn{4}{|c|}{$\begin{array}{c}\text { Tingkat mutu bata beton } \\
\text { pejal }\end{array}$} & \multicolumn{4}{|c|}{$\begin{array}{c}\text { Tingkat mutu bata beton } \\
\text { berlobang }\end{array}$} \\
\hline & & $\mathrm{I}$ & II & III & IV & $\mathrm{I}$ & II & III & IV \\
\hline $\begin{array}{l}\text { Kuat tekan bruto } \\
\text { rata-rata min. }\end{array}$ & $\mathrm{kg} / \mathrm{cm}^{2}$ & 100 & 70 & 40 & 25 & 70 & 50 & 35 & 20 \\
\hline $\begin{array}{l}\text { Kuat tekan bruto } \\
\text { masing-masing } \\
\text { benda uji min. }\end{array}$ & $\mathrm{kg} / \mathrm{cm}^{2}$ & 90 & 65 & 35 & 21 & 65 & 45 & 30 & 17 \\
\hline $\begin{array}{l}\text { Penyerapan air } \\
\text { rata-rata maks. }\end{array}$ & $\%$ & 25 & 35 & - & - & 25 & 35 & - & - \\
\hline
\end{tabular}

Dimana bata semen diklasifikasikan menjadi 4 tingkat mutu sebagai berikut :

1. Bata semen dengan mutu I adalah bata semen untuk konstruksi yang memikul beban dan dapat digunakan pula untuk konstruksi yang tidak terlindung.

2. Bata semen dengan mutu II adalah bata semen yang digunakan untuk konstruksi yang memikul beban. Tetapi penggunaanya hanya untuk konstruksi yang terlindung dari cuaca luar (untuk konstruksi di bawah atap). 
Kabir, Dahri. batu apung, fly ash, mortar.

3. Bata semen dengan mutu III adalah bata semen yang digunakan hanya untuk hal-hal seperti tersebut dalam jenis IV. Hanya permukaan dinding/konstruksi dari bata semen tersebut boleh tidak diplester.

4. Bata semen dengan mutu IV adalah bata semen digunakan hanya untuk konstruksi yang tidak memikul beban dinding.

\section{METODE PENELITIAN}

Metode penelitian yang dipergunakan adalah dengan cara menguji benda coba bentuk kubus mortar ukuran $(50 \times 50 \times 50) \mathrm{mm}$. Kekentalan campuran mortar diukur dengan flowmeter, kelelehan atau flow yang disyaratkan 110\%-120\%. Komposisi campuran mortar 1 PC: 4 PS tanpa penambahan fly ash sebagai variabel tetap atau perbandingan 500 gram semen portland dengan 2000 gram pasir apung dan benda uji yang dibuat dengan penambahan fly ash setiap variasi $10 \%$ terhadap berat semen sebagai variabel bebas. Proses penelitian ini dilakukan dengan 6 tahap antara lain: tahap persiapan bahan dan alat, tahap pengujian bahan, tahap analisa kebutuhan bahan, tahap pencetakan, tahap perawatan, dan tahap pengujian.

\section{Tahap persiapan bahan dan alat}

Bahan-bahan yang dipakai dalam penelitian ini adalah: semen portland tipe I, fly ash batubara dari PLTU Rum, agregat halus menggunakan pasir apung dari quarry di Kota Tidore Kepulauan. Alat yang dipergunakan adalah ayakan satu set dengan ukuran mata ayakan mulai 0,15 mm sampai dengan 4,75 mm; timbangan, digitial; gelas ukur, dipakai untuk mengukur volume air; kerucut Abrams dan tongkat penusuknya, dipakai untuk mengukur nilai konsistensi adukan (slump); cetakan kubus, digunakan untuk mencetak benda uji dengan ukuran sisi $5 \mathrm{~cm} \times 5 \mathrm{~cm} \times 5 \mathrm{~cm}$; mesin pengaduk (mixer), digunakan untuk mencampur dan mengaduk mortar kapasitas 5 liter; mesin uji tekan Compression Machine, digunakan untuk menguji kuat tekan mortar kapasitas $200 \mathrm{kN}$.

\section{Tahap pengujian bahan}

Pelaksanaan penelitian dimulai dari pemeriksaan bahan susun sampai dengan pengujian kuat tekan benda uji. Secara garis besar penelitian meliputi: pemeriksaan agregat halus pasir apung, fly ash: analisa saringan agregat halus, berat jenis dan penyerapan agregat halus, berat isi agregat halus, dan kadar air agregat halus;

\section{Tahap analisa kebutuhan bahan}

Perhitungan rencana campuran (Mix Design). Metode perhitungan menggunakan cara yang dikeluarkan Badan Standarisasi Nasional (BSN) dan dimuat dalam buku Standar Nasional Indonesia, Tata Cara Pembuatan Rencana Mortar SNI 03-6882- 2002, dengan nilai faktor air semen maksimum ditetapkan 0,50 (Faktor air semen atau f.a.s. yang dipakai dalam penelitian ini disamakan pada semua variasi campuran) dan nilai konsistensi dengan flow meter ditetapkan antara (110-120)\% dengan pertimbangan adukan mortar dapat diaduk, diangkut, dan dikerjakan dengan mudah dengan atau cara manual. Dalam penelitian ini akan dilakukan mix design dengan menggunakan fly ash sebagai bahan tambah. Hasil analisa selanjutnya dibuat benda uji dengan kubus ukuran $5 \mathrm{~cm} \times 5 \mathrm{~cm} \times 5 \mathrm{~cm}$, dengan 5 variasi campuran yaitu mortar tanpa fly ash (BN), mortar dengan fly ash 10\% (B1), $20 \%$ (B2), 30\% (B3), 40\% (B4) dan 
50\% (B5), masing-masing variasi campuran terdiri dari 10 sampel, sehingga total benda uji sebanyak 60 buah;

\section{Tahap Pencetakan}

Pengadukan dengan mortar mixer kurang lebih 2 menit. Pencetakan, untuk setiap macam bahan campurandengan faktor air semen yang sama dibuat dalam satu adukan sejumlah 12 buah kubus, mortar dimasukkan dalam cetakan kubus dan dipadatkan dengan beban $25 \mathrm{kN}$. Selanjutnya didiamkan dalam cetakan selama 24 jam. Alat yang digunakan untuk mencetak mortar seperti pada gambar 1. Komposisi benda uji ditampilkan pada Tabel 2.

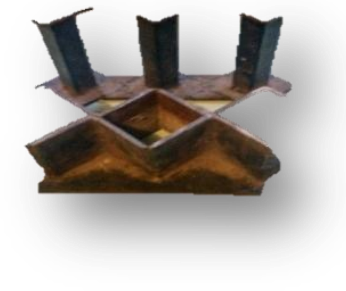

1.a. Alat penekan

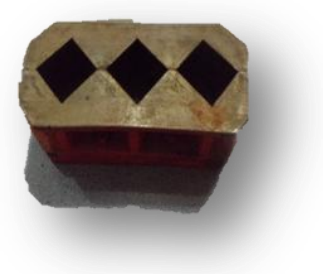

1.b. Cetakan mortar

Gambar 1. Alat pencetak mortar

Tabel 2. Komposisi Benda Uji

\begin{tabular}{ccccccc}
\hline $\begin{array}{c}\text { Jumlah } \\
\text { sampel }\end{array}$ & $\begin{array}{c}\text { Luasan } \\
\text { per } \\
\text { sampel }\end{array}$ & \multicolumn{2}{c}{$\begin{array}{c}\text { Pembacaan } \\
\text { tekanan pada dial }\end{array}$} & $\begin{array}{c}\text { Limbah batubara } \\
\text { (fly ash) }\end{array}$ & $\begin{array}{c}\text { Luasan } \\
\text { keseluruhan }\end{array}$ & $\begin{array}{c}\text { Pembebanan } \\
\text { per } \\
\text { sampel }\end{array}$ \\
\hline (buah) & $\left(\mathrm{mm}^{2}\right)$ & $(\mathrm{kN})$ & $(\mathrm{N})$ & $(\%)$ & $\left(\mathrm{mm}^{2}\right)$ & $(\mathrm{kN})$ \\
\hline 10 & 2500 & 75 & 75000 & 0 & 7500 & 25 \\
10 & 2500 & 75 & 75000 & 10 & 7500 & 25 \\
10 & 2500 & 75 & 75000 & 20 & 7500 & 25 \\
10 & 2500 & 75 & 75000 & 30 & 7500 & 25 \\
10 & 2500 & 75 & 75000 & 40 & 7500 & 25 \\
10 & 2500 & 75 & 75000 & 50 & 7500 & 25 \\
\hline
\end{tabular}

\section{Tahap Perawatan}

Perawatan, dilakukan dengan cara membuka cetakan setelah 24 jam dan benda uji diberi tanda (kode) sesuai komposisi dan penambahan bahan tambah, kemudian direndam dalam bak perendaman sampai dengan umur uji selama 28 hari. Perendaman dapat dilihat pada gambar 1a dan $1 b$.

\section{Tahap Pengujian}

Pengujian, benda uji kubus mortar diuji kekuatan tekannya pada umur 28 hari. Setelah cukup 28 hari dalam perawatan selanjutnyan benda uji diangkat dan diangin-anginkan selama 24 jam, selanjutnya ditimbang, diukur dimensinya, kemudian diuji dengan mesin tekan dan dicatat beban tekan maksimumnya. Kekuatan tekan mortar pasir apung dihitung dengan menggunakan persamaan 1 berikut. 
$\sigma=\frac{P}{A}$

Dimana :

$\mathrm{P}=$ beban maksimum $(\mathrm{kg})$

$\mathrm{A}=$ luas penampang benda uji $\left(\mathrm{cm}^{2}\right)$

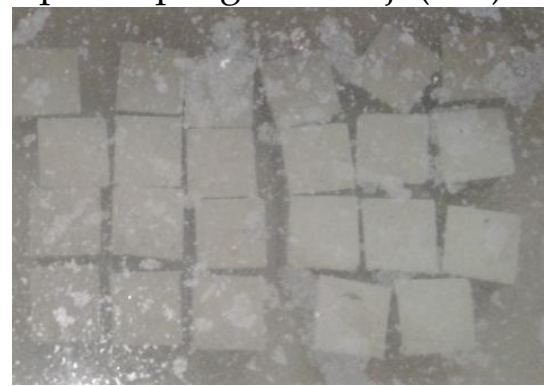

2.a. Perendaman benda uji

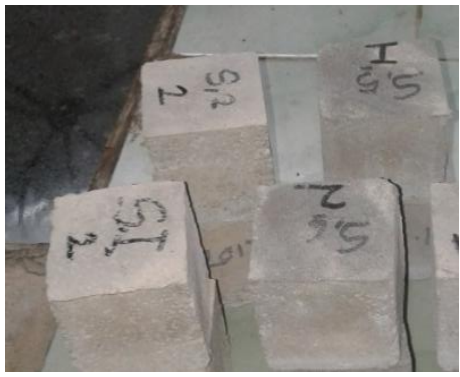

2.b. Benda uji siap untuk diuji tekan

Gambar 2. Benda uji mortar batu apung

\section{HASIL DAN PEMBAHASAN}

\section{Karakteristik Agregat Halus}

Pengujian agregat yang dilakukan dalam penelitian ini meliputi pengujian kadar lumpur, specific grafity, berat volume agregat, dan modulus kehalusan. Hasil-hasil pengujian tersebut disajikan dalam Tabel. 3.

Berdasarkan Tabel 3 dapat dijelaskan bahwa kadar lumpur, modulus kehalusan, berat jenis, berat volume diuji sesuai dengan SNI. Pengujian berat volume pada pasir apung lebih ringan, dengan kata lain agregat dapat digunakan untuk campuran bata semen.

Tabel 3. Karakteristik Agregat Pasir Apung

\begin{tabular}{llc}
\hline No & \multicolumn{1}{c}{ Jenis Pengujian } & Hasil Pemeriksaan \\
\hline 1 & Kadar Lumpur & $2,75 \%$ \\
2 & Berat jenis & \\
& Berat Jenis Kering (bulk specific gravity) & 1,57 \\
& bert jenis kering permukaan jenuh (saturated & 2,50 \\
& surface dry) & 1,85 \\
& Berat jenis semu (apparent specific gravity) & $9,90 \%$ \\
& Penyerapan (absorption) & 0,78 \\
3 & Berat volume & 0,70 \\
& Kondisi Padat & $2,88 \%$ \\
\hline & Kondisi lepas & Modulus halus butir (MHB) \\
\hline
\end{tabular}

\section{Karakteristik Mortar Pasir Apung}

\section{Penyerapan air mortar pasir apung}

Hubungan antara penggunaan fly ash dengan besarnya penyerapan air dapat dilihat pada gambar 2 . 


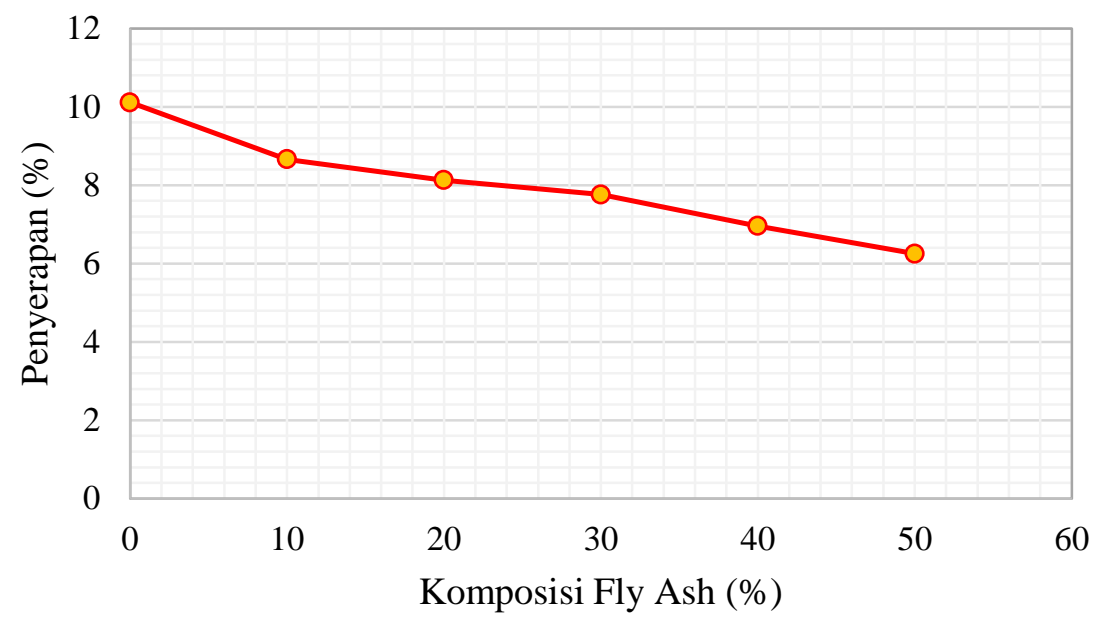

Gambar 3. Hubungan antara penggunaan fly ash dan penyerapan air mortar

Berdasarkan gambar 3, dapat dilihat bahwa dengan peningkatan kompisisi fly ash yang ditambahkan ke dalam campuran mortar pasir apung maka akan mempengaruhi kinerja penyerapan dari mortar pasir apung tersebut. Dimana semakin meningkat komposisi fly ash dalam mortar pasir apung cenderung untuk menurunkan kemampuan penyerapan dari mortar pasir apung. Ini disebabkan karena fly ash bersifat filler, jadi mampu mengisi rongga sehingga void pada mortar pasir apung semakin kecil yang berimplikasi pada daya serap mortar pasir apung menurun.

\section{Kuat Tekan Mortar Pasir Apung}

Berdasarkan gambar 3, dapat dilihat bahwa dengan peningkatan kompisisi fly ash yang ditambahkan ke dalam campuran mortar pasir apung maka akan mempengaruhi kuat tekan dari mortar pasir apung tersebut. Dimana semakin meningkat komposisi fly ash dalam mortar pasir apung, cenderung untuk meningkatkan kuat tekan mortar pasir apung. Ini disebabkan karena fly ash bersifat filler, jadi mampu mengisi rongga sehingga void pada mortar pasir apung semakin kecil yang berimplikasi daya lekat antara pasir apung dengan semen dan fly ash semakin kuat, disebabkan salah satu sifat dari fly ash adalah bersifat cementious atau mengikat. Dapat disimpulkan bahwa dengan penggunaan fly ash sebagai bahan tambah pada campuran mortar pasir apung dapat memperbaiki kinerja kuat tekan mortar.

Hubungan pencampuran fly ash terhadap kuat tekan bata semen rata-rata secara lengkap dapat dilihat pada gambar 4 . 


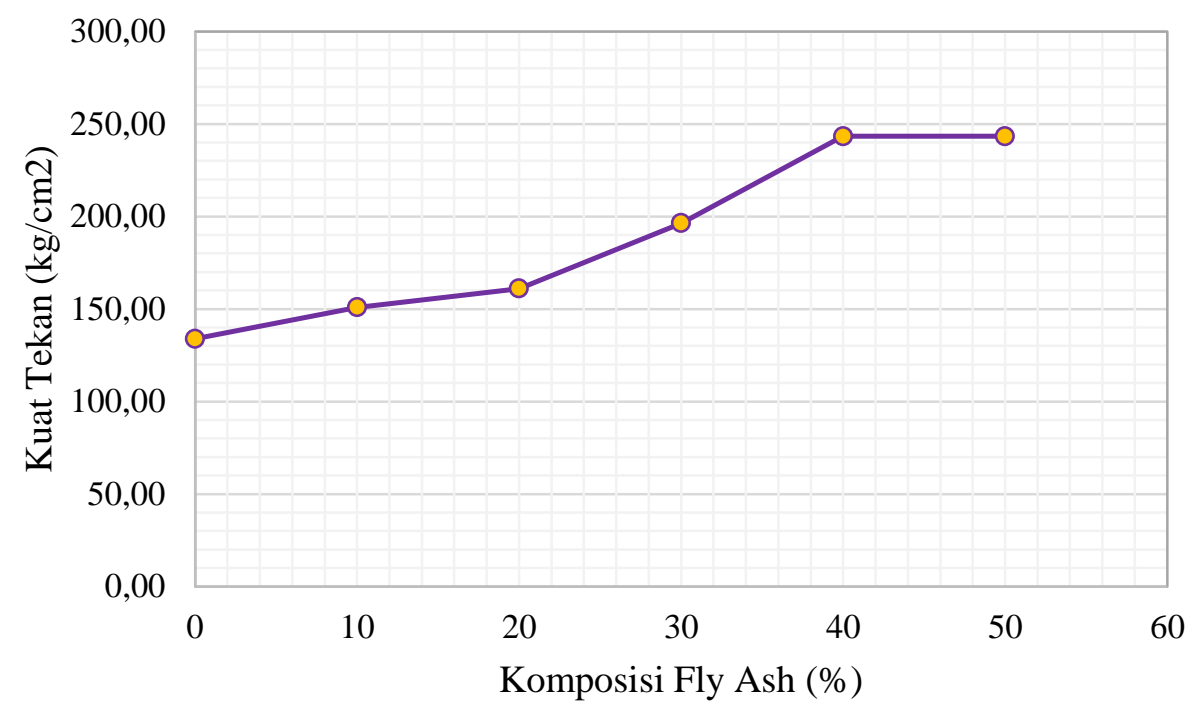

Gambar 4. Hubungan antara penggunaan fly ash dan kuat tekan mortar mortar

\section{Klasifikasi Mortar Pasir Apung}

Klasifikasi hasil pengujian mortar pasir apung dapat dilihat pada tabel 4 berikut ini :

Tabel 4. Klasifikasi Bata Semen Pasir Apung fly ash Sebagai Bahan Tambah

\begin{tabular}{cccccc}
\hline $\begin{array}{c}\text { Presentase } \\
\text { fly ash }\end{array}$ & $\begin{array}{c}\text { Kuat Tekan Bata } \\
\text { semen }\end{array}$ & \multicolumn{2}{c}{ Syarat Fisis } & $\begin{array}{c}\text { Syarat Fisis } \\
\text { Penyerapan } \\
(\text { max })\end{array}$ & $\begin{array}{c}\text { Penyerapan } \\
\text { Bata semen }\end{array}$ \\
$(\%)$ & $\left(\mathrm{Kg} / \mathrm{Cm}^{2}\right)$ & $\left(\mathrm{Kg} / \mathrm{Cm}^{2}\right)$ & $\begin{array}{c}\text { Tingkat } \\
\text { Mutu }\end{array}$ & $(\%)$ & $(\%)$ \\
\hline 0 & 133.88 & 100 & I & 25 & 10,11 \\
10 & 150.87 & 100 & I & 25 & 8,66 \\
20 & 161.06 & 100 & I & 25 & 8,13 \\
30 & 196.40 & 100 & I & 25 & 7,76 \\
40 & 243.29 & 100 & I & 25 & 6,96 \\
50 & 243.29 & 100 & I & 25 & 6,25 \\
\hline
\end{tabular}

Berdasarkan Tabel 4 dapat dilihat, bahwa mortar pasir apung dengan menggunakan bahan tambah fly ash dikategorikan sebagai mortar kelas I.

\section{KESIMPULAN}

Berdasarkan hasil penelitian, dapat disimpulkan sebagai berikut:

1. Penggunaan fly ash sebagai bahan tambah pada pencampuran mortar pasir apung $0 \%, 10$ $\%, 20 \%, 30 \%, 40 \%, 50 \%$ terhadap berat semen dapat memperbaiki kinerja penyerapan dari mortar pasir apung tersebut.

2. Penggunaan $f l y$ ash sebagai bahan tambah pada pencampuran mortar pasir apung $0 \%, 10$ $\%, 20 \%, 30 \%, 40 \%, 50 \%$ terhadap berat semen dapat meningkatkan kinerja kuat tekan dari mortar pasir apung tersebut. 
3. Penggunaan $f l y$ ash sebagai bahan tambah pada pencampuran mortar pasir apung $0 \%$, $10 \%, 20 \%, 30 \%, 40 \%, 50 \%$ terhadap berat semen dan pemberian beban pada proses pembuatan mortar semen dapat memperbaiki parameter terhadap tingkat mutu mortar sehingga mortar yang dihasilkan masuk dalam kategori tingkat mutu I.

\section{DAFTAR PUSTAKA}

Haryanti, N.H., 2015. Kuat Tekan Batan Ringan Dengan Campuran Abu Terbang PLTU AsamAsam Kalimantan Selatan. Jurnal Fisika Flux 12(1) hlm:20-30

Kusdiyono dan Rochadi, M.T., 2012. Pengaruh Pemanfaatan Limbah Batu Bara (fly ash) Terhadap Kekuatan Tekan Mortar Type M. Wahana Teknik Sipil 17 (2) hlm: 97-106

Mistry, S et al, 2011. Fly Ash Bricks Masonry: An Experimental Study. National Conference on Recent Trends in Engineering \& Technology.

SNI 03-0349-1998. bata beton untuk pasangan dinding. Standar Nasional Indonesia

SNI 03-6882-2002, pengujian mortar. Standar Nasional Indonesia

SNI 03-6825-2002. metode pengujian kuat tekan mortar untuk pekerjaan sipil. Standar Nasional Indonesia

Simanullang, D.Y. 2014. Kajian Kuat Tekan Mortar Menggunakan Pasir Sungai Dan Pasir Apung Dengan Bahan Tambah Fly Ash Dan Complast Dengan Perawatan (Curing). Jurnal Teknik Sipil dan Lingkungan, hlm 621-631

Sultan, M.A dan Yudasputra, M.T. 2017. Pengaruh Tekanan pada Pembuatan Bata Semen Berbahan Dasar Pasir Apung). Prosiding Simposium II UNIID, hlm 360-364.

Sultan, M.A et al. 2018. Effect of Pressure and Making of Cement Bricks from Pumice. Pengaruh Tekanan pada Pembuatan Bata Semen Berbahan Dasar Pasir Apung). International Journal of Civil Engineering and Technology (IJCIET) 9(5): pp:1084-1091

Ola, A.L dan Silaban, D.P. 2018. Komposit Bata Beton Ringan dari Fly Ash dan Bottom Ash Limbah Batubara Pabrik Minyak Nabati. Jurnal Riset Teknologi Industri 12(1) hlm:4755.

Wenno, R. dkk. 2014. Kuat Tekan Mortar dengan Menggunakan Abu Terbang (Fly Ash) Asal PLTU Amurang sebagai Subtitusi Parsial Semen. Jurnal Sipil Statik 5(2) hlm:252-259 